\title{
PUNISHMENT WITHOUT LAW: HOW ENDS JUSTIFY THE MEANS IN MARITAL RAPE
}

\author{
Sir Ivan Lawrence QC*
}

\section{SUMMARY}

In marital rape cases, the appellate courts have either ignored or dismissed established principles of law: that Parliament is sovereign and alone can make new laws, and that the House of Lords cannot change laws in contradiction to the clear intention of Parliament. Now, the courts are developing a test of forseeability, that not only defeats the rule against retrospectivity but goes further to defy common-sense, thus proving, in this area of the law that, ends justify the means.

\section{INTRODUCTION}

It is one of the paradoxes of modern society that, while neither Parliament nor the courts have thought it necessary to protect adults from the causal tide of sexual titillation generated by tabloid newspapers, television and cinema, both institutions have gone into spasm at any mention of the crime of rape. No longer is a defendant protected from false allegation by the requirement of corroboration $^{1}$ nor by the ability to cross-examine an alleging victim on her past sexual proclivities. ${ }^{2}$ In 1992, the Court of $\mathrm{Appeal}^{3}$ and the House of Lords, ${ }^{4}$ throwing constitutional restraint to the winds, even decided to overrule Parliament and to create a crime of marital rape. The European Court of Human Rights, in confirming the conviction and reasoning of the appellate courts in that case, ${ }^{5}$ apparently saw no incompatibility between Article 7 of the European Convention (no retrospective convictions) ${ }^{6}$ and the fact that the alleged rape in that case had taken place three years before the crime of

\footnotetext{
* Clarendon Chambers, Lincoln’s Inn; Master Bencher Inner Temple, London; and Visiting Professor in Law, University of Buckingham.

${ }^{1}$ Criminal Justice and Public Order Act 1994 s 32.

${ }^{2}$ Youth Justice and Criminal Evidence Act 1999 s 41.

${ }^{3} R$ v R (1991) 2 All ER 257.

${ }^{4} R \vee R(1992) 1$ AC 599.

${ }^{5} S W$ and $C R v$ UK 21 EHRR 363.

${ }^{6}$ Article 7 of the European Convention on Human Rights states: "7 (1) No one shall be held guilty of any criminal offence on account of any act or omission which did not constitute a criminal offence under national or international law at the time when it was committed."
} 


\section{THE DENNING LAW JOURNAL}

marital rape was declared to exist by the courts. Parliament, faced with a "fait accomplis," confirmed that marital rape was henceforth a statutory offence, without any debate in either House, in $1994 .^{7}$

In 2003 and 2004, two more decisions of the Court of Appeal, in upholding marital rape convictions, have ignored the law against retrospectivity. ${ }^{8}$ The reasoning in the latter case is so bizarre that, taken together with the other decisions, there is a question mark over whether the courts can any longer be considered to be protecting the rights of the individual in our society.

\section{THE CASES}

On March $18^{\text {th }}$ 2004, the Court of Appeal, in a reserved judgement, in the case of $R v$ Crooks, ${ }^{9}$ rejected an appeal against a conviction for rape which had taken place upon the appellant's wife in 1970. In May 2003, the Court of Appeal, in an unreserved judgement, in the case of $R v$ Laskey, ${ }^{10}$ rejected an appeal against convictions for two offences of rape upon the appellant's wife which had taken place between 1988 and 1991. These cases followed the momentous decision in $R v R$, when the Court of Appeal ${ }^{11}$ and then the House of Lords, ${ }^{12}$ rejected an appeal against a conviction for attempted rape on the appellant's wife which had taken place in 1989.

In $R \vee R$, the defendant admitted at his trial that, after his wife had told him that she wanted a divorce and had left the matrimonial home, he had forced his way into her house and had attempted to have intercourse with her against her will, causing her actual bodily harm. The trial judge, Mr Justice Owen, ruled that, assuming there had been in marriage a general consent to sexual intercourse, the wife could unilaterally remove herself from cohabitation and thus indicate that consent to intercourse had been terminated. ${ }^{13} \mathrm{R}$ then changed his plea to guilty of attempted rape. The Judicial Committee of the House of Lords, in upholding the decision and argument in the Court of Appeal, decided that marital rape, not then a criminal offence, was henceforth to be recognised as one. ${ }^{14}$ On the further appeal, the European

\footnotetext{
7 The Criminal Justice and Public Order Act 1994 removed unlawful from the definition of rape amending Sexual Offences Act 1956 s 1.

${ }^{8}$ Laskey v R (2003) EWCA Crim 1512 and Crooks v R (2004) EWCA Crim 292.

${ }^{9}$ Crooks v R (2004) EWCA Crim 292.

${ }^{10}$ Laskey $v$ R (2003) EWCA Crim 1512.

${ }^{11} R v R$ (1991) 2 All ER 257.

${ }^{12}$ See note 4 above.

${ }^{13} R v R$ (1991) 2 All ER at 747.

${ }^{14}$ See note 4 above.
} 


\section{THE DENNING LAW JOURNAL}

Court of Human Rights held, ${ }^{15}$ that there had been no breach of Article 7 of the Convention, which declares against the retrospective application of the criminal law.

In $R v$ Laskey, ${ }^{16}$ the jury found that on at least two occasions before 1991, the defendant had intercourse with his wife against her will, once, after drugging her. Nevertheless, she continued living with him as his wife, and having voluntary intercourse with him until the marriage ended in $1995 .{ }^{17} \mathrm{He}$ was convicted on fifteen counts of the twenty-six charged, and sentenced to ten life sentences of imprisonment for the rapes and buggeries, and fourteen years imprisonment for four counts of indecent assault and one indecency with a child. He appealed against the two rape counts on his wife, on the ground that there existed at the time no such crime of marital rape. A request for a certificate to appeal to the House of Lords was refused. An application to appeal has been made to the European Court of Human Rights.

In $R v$ Crooks, ${ }^{18}$ the defendant was convicted of rape on his wife in 1970, and a number of other counts alleging sexual and violent offences against four different women between 1967 and 1987, for which he was jailed for a total of 12 years. His ground of appeal was, that since his behaviour would not have been considered to be rape by either Parliament or the courts in 1970, it had been an abuse of process to pursue the allegation to trial. He also argued that the conviction was in contravention of Article 7 of the European Convention. Lord Justice Judge, in delivering the judgement of the Court of Appeal, said that: "a man may properly be convicted today of having raped his wife before the fiction of deemed consent was finally dissipated in March 1991 (sic)." The Court took the view that, since the whole purpose of the Convention was to protect someone from inhuman or degrading treatment, the husband could not rely upon Article 7. Furthermore, Article 7 (2), which allowed a retrospective conviction where the act was criminal according to the general principles of law recognised by civilised nations, provided ample justification for a husband's trial and punishment for the rape of his wife. The Court, begging the various questions raised by the case, simply concluded: "This appellant knew perfectly well that to rape his wife was wrong..."19

\footnotetext{
${ }^{15} S$ W and $C R v$ UK 21 EHRR 363.

${ }^{16}$ See note 8 above.

${ }^{17}$ It is not wholly surprising that his denial of force or the use of drugs was rejected by the jury, since the case against him was that he was responsible for serious violent sexual abuse, including rape and buggery on no less than seventeen complainants, all vulnerable because of their ages, personalities or character, over a period of thirty years.

${ }^{18}$ See note 9 above.

${ }^{19}$ See note 9 above, para 26.
} 


\section{THE DEFENCE OF MARRIAGE TO A CHARGE OF RAPE AT COMMON LAW}

It is indisputable that at least from $1736^{20}$ until 1992, the settled law provided that, being married to the complainant, was a defence to a charge of rape. ${ }^{21}$ The Common Law had developed exceptions. In effect, these arose where there was, realistically, no longer a marriage; for example where there existed a "decree nisi," 22 a judicial separation order, ${ }^{23}$ a separation agreement, ${ }^{24}$ a non-molestation order, ${ }^{25}$ or a court undertaking not to molest. Furthermore, in $R v R$, the wife had left the matrimonial home and made clear that she did not want to remain married to her husband: he broke in to where she was living with her son and attempted to force himself upon her. None of these exceptions applied in $R v$ Laskey or $R v$ Crooks. R, Laskey, and Crooks were each, therefore, convicted and sentenced to long terms of imprisonment for a crime which was understood by the courts not to have existed when they had (or in R's case, attempted) non-consensual intercourse with their wives. ${ }^{26}$

How did this happen? For the answer we must look at three conclusions arrived at by the House of Lords in $R v R$, which are surprising because they appear to have contradicted established principles of English law. First, it held that the time had indeed come for it to be judicially declared that there was now a crime of marital rape. ${ }^{27}$ In so deciding, it was either actually, or in effect, creating a new criminal offence. This was a breach of the constitutional principle that it is for Parliament alone, because it is democratically elected, to make new laws. Secondly, that the Judicial Committee of the House of Lords had the right to ignore the Sexual Offences (Amendment) Act (1976), its

\footnotetext{
${ }^{10}$ Hale's History of the Pleas of the Crown (1736) Vol 1 Chap 58 p 629. Stated that a husband could not be guilty of raping his wife because she had consented to sexual intercourse with him and could not retract that consent during marriage.

${ }^{21} R v$ Steele (1976) 65 CAR at 22, where Lane LCJ, quoting Hale's Pleas of the Crown, said: " there is no doubt about the general principle that a man cannot be guilty of raping his wife”: and see Smith and Hogan Criminal Law (10 ${ }^{\text {th }}$ edition 2002) at $\mathrm{p} 472$ and the reasoning of Lord Keith in $R v R$ at note 4 above.

${ }^{22} R$ v O’Brien (1974) 3 All ER 663.

${ }^{23} R v$ Clarke (1949) 2 All ER 448.

${ }^{24} R$ v Kowalski (1987) 86 CAR 339.

${ }^{25} R v$ Miller (1954) 2 QB 282.

26 The Home Office is unable to say how many men, have been convicted and imprisoned for raping their wives between 1992 and 1995, but there may well have been a number. Compensation claims, if they have been wrongly convicted, might be considerable.

${ }^{27}$ See note 4 above per Lord Keith of Kinkel at 623B: “..the Act of 1976 presents no obstacle to this House declaring that in modern times the supposed marital exemption in rape forms no part of the law of England.”
} 


\section{THE DENNING LAW JOURNAL}

proceedings and Parliament's subsequent approach to the matter which had clearly indicated Parliament's contrary intention. Thirdly, in effect, that the rule against making a criminal offence retrospective, could be ignored in any case where the accused ought to have foreseen that the time had come when a law might well be passed at some time in the future to make such activity criminal. ${ }^{28}$

\section{CAN THE HOUSE OF LORDS CREATE A CRIMINAL OFFENCE?}

Parliament has, throughout the past two centuries, considered that it was for Parliament, not the judges, to make new law. The Judicial Committee has always been able to develop the law by interpretation, but not if it was effectively creating a new criminal offence. In 1962, for example, it had asserted its right to create new common law offences to protect public morality, ${ }^{29}$ but it later disavowed that decision, laying down the principle that the creation of new crimes was a matter for Parliament. ${ }^{30}$ Nor can the courts strike down a statute which does not comply with our human rights obligations: they can only declare it to be incompatible and refer it back to Parliament for its consideration. ${ }^{31}$ Lord Lowry made clear what the limits of the Judicial Committee's powers should be, and has laid down guidelines. In $1995,{ }^{32}$ he said that judges should beware of imposing a remedy where the solution to a problem is doubtful: be cautious about making changes if Parliament had declined to correct a known problem, or had legislated while leaving the problem untouched: that the judges were not suited to deal with disputed matters of social policy: and that fundamental legal doctrines should not be lightly set aside. That it was for Parliament to make procedural changes was also well established. ${ }^{33}$

\footnotetext{
${ }^{28}$ See note 4 above.

${ }^{29}$ DPP v Shaw (1962) AC 226.

${ }^{30}$ DPP v Knuller (1973) AC 435.

${ }^{31}$ Human Rights Act 1998 s 4.

${ }^{32}$ Per Lord Lowry in C v DPP (1995) 2 All ER 43

33 e.g Hoskyn $v$ Commissioner of Police for the Metropolis (1979) AC 474 (spouses immunity from giving evidence): see also per Simon Brown LJ in Ministry of Defence ex parte Smith and others (1995) 1 All ER pp 447-8 (homosexuality as a bar to membership of the armed services).
} 


\section{THE DENNING LAW JOURNAL}

In cases of marital rape, the judges nearly always considered themselves to have been bound by Parliament. ${ }^{34}$ And the former Court of Appeal judge, Sir Christopher Staughton said of $R \vee R:^{35}$

"I do not see how it can be properly described as an 'extension'. It changed what was substantive law established for a very long time... I hold no brief for rapacious husbands... but the decision of the Court ...in that case was a clear example of inappropriate legislation by judges."

Even in his judgement in the Court of Appeal in $R v R$, Lord Lane LCJ drew a distinction between creating a new offence and "removal of a common law fiction" when he said:

" We take the view that the time has now arrived when the law should declare that a rapist remains a rapist subject to the criminal law, irrespective of his relationship with his victim...... The remaining and no less difficult question is whether... this is an area where the court should step aside to leave the matter to the Parliamentary process. This is not the creation of a new offence, it is the removal of a common law fiction which has become anachronistic and offensive and we consider that it is our duty having reached that conclusion to act upon it."

Of this conclusion, with which the House of Lords later agreed, the academics were scathing:

“...The creation of offences is for Parliament alone and ..the role of the Judiciary is to interpret rather than to add or subtract": ${ }^{36}$

"...It is for Parliament, not the criminal courts, to make extensions of the criminal law, however desirable they may be": ${ }^{37}$

\footnotetext{
${ }^{34}$ See Rougier $\mathrm{J}$ in $R v J$ (1991) 1 All E.R. 759 and Swinton Thomas $\mathrm{J}$ in $R v S$ (1991) (unreported): although see Simon Brown J in $R \vee C$ (1991) 1 All ER 755, where the defendant was acquitted.

${ }^{35}$ Inner Temple Millineum lecture $29^{\text {th }}$ November 2000.

${ }^{36}$ Professor Andrew Ashworth, Vinerian Professor of Law at Oxford University at (1991) 107 LQR 420.

${ }^{37}$ Professor Sir John Smith QC, formerly Professor of Law at Nottingham University and author of the leading textbook on criminal law at (1991) CLR 478.
} 


\title{
THE DENNING LAW JOURNAL
}

\begin{abstract}
"The Courts have gone beyond the bounds of their legitimate law-making powers... it is clear that justice is best served by statutory reform.”38
\end{abstract}

Other academics have also expressed their disapproval. ${ }^{39}$

The Law Commission, ${ }^{40}$ in making its provisional proposal that "the present marital immunity be abolished in all cases," did not suggest that the courts could make the necessary change by judicial creativity: it assumed that the law would have to be changed by statute. Our conclusion must be that the House of Lords does not have the authority to create criminal offences, and to have done so in $R v R$ was "ultra vires" its constitutional powers.

In 1994, Parliament accepted that the defence of marriage should no longer exist. ${ }^{41}$ Interestingly, there was no debate about the matter, and the provision went through without any discussion in either House of Parliament.

Even if it could legitimately be argued that this was no more than the removal of an anachronistic fiction and not the creation of a new offence, could the House of Lords properly ignore a clear Parliamentary decision that marital rape should not be a crime?

\section{PARLIAMENT'S INTENTION}

It is indisputable that, before 1994, Parliament had manifested a clear intention that marital rape should not be a crime. The Sexual Offences (Amendment) Bill (1976) section 1 (1) provided a statutory definition of rape in terms which gave effect to the report of the Advisory Group on the Law of Rape. $^{42}$ It specifically defined the offence as: "unlawful sexual intercourse", unlawful having no other meaning than outside marriage. When the Bill was introduced as a Private Members measure by Robin Corbett MP (now Lord Corbett), it had, in Clause 1(3), provided for a crime of marital rape, but the Minister of State at the Home Office, Mr Brynmor John, expressly moved amendment 11 to delete that clause from the Bill. ${ }^{43}$ In this he had the support of the Opposition and most of the MPs debating the Bill. No vote was necessary and none was moved. During the passage of the Bill through both Houses, no attempt was made to restore the clause. A number of reasons were given in that debate for what, in the eyes of the courts in 1992, had seemed to

\footnotetext{
${ }^{38}$ Marianne Giles, lecturer in Law at the University of Kent at (1992) CLR 407.

${ }^{39}$ Dr A T H Smith (1984) 100 LQR and T Jones (1990) CLR 292.

${ }^{40}$ Working Paper 116 “Rape within Marriage”(September 1990).

${ }^{41}$ Criminal Justice and Public Order Act 1994 s 142.

${ }^{42}$ Home Office, Report of the Advisory Group on the Law of Rape, December 1975, Cmnd 6352.

${ }^{43}$ Vol 911, House of Commons Official Report (1976) cols 1957 et seq.
} 


\section{THE DENNING LAW JOURNAL}

be "anachronistic and offensive," but which sixteen years earlier had seemed sensible to both the Government and the Opposition.

The Minister ${ }^{44}$ argued that insufficient consideration had been given to the effect of the proposal upon the status of marriage, and particularly that, since women often complained about their husbands and then later changed their minds, any legislation would have to take account of that factor and this the proposed clause did not do. Such a change, he said, would lead to cynicism from those who had to enforce the law and would be likely to do more harm than good. Other MPs, ${ }^{45}$ with day to day experience of the working of the law, feared that unscrupulous wives would be given an easy weapon for blackmailing their husbands into agreeing to a divorce, with its consequences for substantial financial settlements. The mere allegation of rape, even without any evidence of violence, would be a terrible slur, difficult or impossible to rebut. Indeed, if there had then been, as there is now, no need for a judicial warning to be given to a jury about the danger of convicting without corroboration, ${ }^{46}$ and the statutory restrictions which now exist on the cross-examination of a rape victims, ${ }^{47}$ Parliamentary objections to marital rape might have been even stronger. It was also argued, that since no defence of being married to the complainant was available for the crimes of attempted murder, grievous and actual bodily harm, and the courts had power to order non-molestation, non-cohabitation, separation and an end to the marriage, a wife was well enough protected by the existing law in the event of physical violence being threatened or done to her. The Minister said that the question of whether the marital defence to rape should remain, was then being considered by the Criminal Law Revision Committee, and if it recommended a change in the law, the Government would act. In the event, eight years later, in 1984, that Committee recommended ${ }^{48}$ that, with the addition of one exception, the law should remain as it was: there should continue to be no crime of marital rape.

Between 1976 and 1992, although Parliament had many opportunities to create a crime of marital rape had it wished to do so, ${ }^{49}$ it took no action in the matter. The intention of Parliament up to 1992, remained perfectly, clear.

\footnotetext{
44 Ibid cols 1953-1954.

${ }^{45}$ Ibid cols 1967-1970.

${ }^{46}$ Criminal Justice and Public Order Act 1994 s 32(1)(b).

${ }^{47}$ Youth Justice and Criminal Evidence Act 1999 ss 41-43.

48 The Fifteenth Report of the Criminal Law Revision Committee, Sexual Offences (Cmnd 9213 of 1984).

49 eg the Sexual Offences Act 1985 and the Criminal Justice Act 1988 which dealt specifically with changes to the Sexual Offences (Amendment) (1976) Act.
} 


\section{THE DENNING LAW JOURNAL}

Since all of Lord Lowry's guidelines ${ }^{50}$ are fulfilled, our conclusion must be that the House of Lords, in $R \vee R$, was also acting "ultra vires" its constitutional powers in ignoring the clear intention of Parliament.

\section{THE REASONING IN $R \boldsymbol{v} R$.}

The Court of Appeal (Lord Lane LCJ, Sir Stephen Brown P, Watkins, Neill, Russell LJs), in $R v R$, dismissed the appeal on the grounds that the fact that the parties were married at the time was no longer a defence to rape. ${ }^{51}$ Leave was granted to appeal to the House of Lords on the certified question: "Is a husband criminally liable for raping his wife?" The House of Lords dismissed the appeal, confirming the Court of Appeal judgement. Argument in that Court turned upon the definition of rape in the 1976 Act viz: "unlawful sexual intercourse with a woman who at the time of the intercourse does not consent to it ..."52 This presented a substantial obstacle to a court wanting to remove the marital rape exception. The appellant argued that "unlawful" could only mean, in this context, "outside marriage" and that that interpretation had been accepted in a series of cases. ${ }^{53}$ In fact, the specific insertion of the word "unlawful" into the definition of rape, had been a clear indication of Parliament's intention to exempt non-consensual marital intercourse from the crime of rape. To remove the obstacle, Lord Keith of Kinkel, delivering the judgement in the House of Lords, said that the word "unlawful" was just "surplusage" and could safely be ignored. He reasoned that if "unlawful" only meant "outside marriage," it did not cover the various exceptions to rape established by the Courts which took place within marriage. ${ }^{54}$ Those exceptions would therefore have been abolished: an unlikely result without specific Parliamentary declaration.

Sir John Smith vehemently criticised this reasoning ${ }^{55}$ and saw no difficulty in reconciling the apparent inconsistencies suggested by Lord Keith. Furthermore, he argued, that to treat the word "unlawful" as mere "surplusage," was to ignore two fundamental rules of statutory interpretation: first, that it is the duty of the court to give a meaning to every word in the

${ }^{50}$ CR v The United Kingdom; SW v The United Kingdom (Case Nos 48/1994/495/577; 47/1994/494/576).

51 (1991) CLR 475.

52 Sexual Offences (Amendment) Act 1976 s.1 (1) (a).

${ }^{53} R v J$ (1991) 1 All E.R. 759: $R$ v S (1991) CLR 301: $S$ v HM Advocate (1989) SLT 469: and $R v$ Chapman (1959) 1 QB 100 - a decision on s 19 Sexual Offences Act 1956 (abduction of an unmarried under 18 year old for the purpose of unlawful sexual intercourse.)

${ }^{54}$ See note 4 above.

${ }^{55}$ See (1992) CLR 208-9: and see Marianne Giles (1992) CLR 407. 


\section{THE DENNING LAW JOURNAL}

section unless no meaning is possible; and secondly, that penal statutes must be strictly construed.

Opinion today might say that the end result was desirable, and indeed Parliament did legislate for marital rape two years later. The statutory definition of the crime of rape was changed to remove the qualification that the intercourse had to be "unlawful" (ie outside marriage), giving effect to the decision of the House of Lords that the word "unlawful" was "surplusage." 56

That does not alter the fact that it was never more than a pretence for the Court of Appeal, and then the House of Lords, to argue that it was doing no more than developing the law, still less that it was really Parliament's intention to remove the marital defence to a charge of rape. Those arguments surely diminish the reputation of the Judicial Committee of the House of Lords as a protector of our laws and the rights therein enshrined. It is not just another example of the adage that "hard cases make bad law": it looks like an acceptance that in our laws, ends can sometimes justify the means. One might even assume that the decision to become "law-maker" in preference to Parliament was deliberate, since to have achieved the same result in $R v R$, it would have only have been necessary to hold that, the wife having removed herself from co-habitation with her husband by leaving the matrimonial home and thus expressing a clear intention to divorce him, the established exceptions to the marital defence would apply. ${ }^{57}$

Even if it could be said to have been acceptable for the House of Lords either to create a new crime or merely to remove a "fictional defence" in the face of a clear Parliamentary intention to the contrary, the question remains: how could such a law be allowed to operate retrospectively?

\section{THE RULE AGAINST RETROSPECTIVITY AND ARTICLE 7?}

Article 7 of the European Convention states:

“7. (1) No one shall be held guilty of any criminal offence on account of any act or omission which did not constitute a criminal offence under national or international law at the time when it was committed....

(2) This article shall not prejudice the trial and punishment of any person for any act or omission which, at the time it was committed, was criminal according to the general principles of law recognised by civilised nations."

\footnotetext{
${ }^{56}$ Criminal Justice and Public Order Act 1994 s 142.

${ }^{57}$ See notes 22, 23, 24 and 25 above.
} 


\section{THE DENNING LAW JOURNAL}

That criminal laws cannot have retrospective effect, has been a longstanding rule of English law: someone can only be guilty of crime if he commits an act which the law expressly, and certainly, forbids at the time he does it. Where, for example, the trial judge held that certain penal provisions of the Immigration Act 1971 had retrospective effect, the conviction was quashed. ${ }^{58}$ The European Convention on Human Rights, prohibits not only the legislative creation of offences which are retrospective, but also the retroactive application of common law offences in order to cover conduct which would not previously have been regarded as a crime. ${ }^{59}$

In $R v R$, the rape offence (attempted rape) took place on $12^{\text {th }}$ November 1989, the wife having left the matrimonial home three weeks earlier. On that date the law was generally accepted by the courts to have still been that of Hale, as amended. It was not until $14^{\text {th }}$ March 1991, when Lord Lane LCJ, speaking for the Court of Appeal, declared that marriage was to be no longer a defence to rape, that any citizen could reasonably have thought that the law had now changed. He was very specific about the change in the law, declaring that: " ...the time has now arrived when the law should declare that a rapist remains a rapist." Until then, he clearly implied, the law had not been so declared. In fact it was not definitively the law until the House of Lords confirmed it to be so in October $1991-2$ years after the non-consensual attempt at intercourse complained of in the case.

How then did the Court of Appeal deal with the obvious issue of retrospectivity? The surprising answer is that they did not do so: it does not appear from the reports that the matter was even raised. Perhaps Lord Lane was skirting around it in the very last paragraph of his reasoning, when he said:
“ ...had we been of the opinion that Hale's proposition was still effective, we would nevertheless have ruled that where, as in the instant case, a wife withdraws from cohabitation in such a way as to make it clear to the husband that so far as she is concerned the marriage is at an end, the husband's immunity is lost." 60

How then did the House of Lords deal with the problem? Again it does not appear, from the reports, that the matter was specifically either raised by Counsel or addressed by the Court. It was concerned only with answering the

\footnotetext{
${ }^{58}$ Waddington v Miah (1974) 1 WLR 683 (HL).

${ }^{59}$ Article 7(1) European Convention on Human Rights applied, for example, in X Ltd and $Y \vee U K 28$ DR 77.

${ }^{60} R \vee R(1991) 2$ WLR at 611.
} 


\section{THE DENNING LAW JOURNAL}

point of law of general public importance it was asked: "Is a husband criminally liable for raping his wife?”

The application of the rule against retrospectivity was, of course, central to R's appeal to the European Court of Human Rights ${ }^{61}$ on the ground that there had been a breach of Article 7. First the Commission expressed the view, by 14 votes to 3, that there had been no such violation, then the Court itself unanimously agreed that there had been no breach of the rule. In its judgement, the Court itself, having said that Article 7 was particularly important: that the rule "nulla poena sine lege" could not be extensively construed to an accused's detriment: that therefore the offence had to be clearly defined by law: and that that requirement would be satisfied where the individual could know from the words of a statute, if need be, with the assistance of the Court's interpretation of it, what acts and omissions would make him criminally liable: went on to say that those matters involved the concepts of accessibility and foreseeability. ${ }^{62}$ Progressive development of the criminal law through judicial law-making was a well-entrenched and necessary part of the UK's tradition and Article 7 could not be read as outlawing the gradual clarification of the rules of criminal liability through judicial interpretation from case to case, provided - and here is the nub - that the resulting development was consistent with the essence of the offence and could reasonably have been foreseen. ${ }^{63}$ The European Court concluded that the state of the law could have been reasonably foreseen, and so there was no breach of Article 7. It is submitted that that conclusion is unsustainable.

Lord Lane LCJ may have stated in the Court of Appeal that the idea that a wife consents to intercourse in any circumstances "can never have been other than a fiction, and fiction is a poor basis for the criminal law" ${ }^{44}$ and the House of Lords may have accepted that view, but the question must be: would anyone, years before those opinions were judicially expressed, have reasonably understood that to have been the position in law? Fiction or not, the courts had certainly accepted the marital defence to be the law for over 250 years. Is it reasonable to expect an ordinary person to have foreseen that the law was the opposite of what the courts themselves had always supposed it to be? What of the principle that before conviction, the law must be certain? ${ }^{65}$ Even if an ordinary man must have realised that the law "might" be changed at some time in the future, what certainty is there that that would happen, since it had not happened over the past century? And where is the

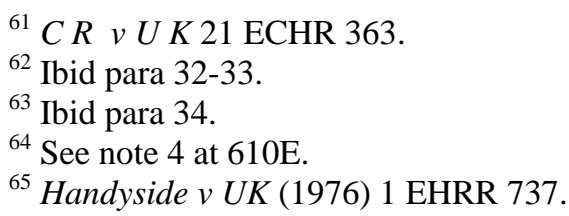




\section{THE DENNING LAW JOURNAL}

certainty that the terms of any future change would cover the situation, for example, of a man who continues to have voluntary intercourse with his wife as in Laskey's case? Equally, such a man might well have heard that, in 1976, Parliament had decided that marriage would remain a defence to rape: is it reasonable to expect him to foresee that the Court of Appeal or the Judicial Committee of the House of Lords would take it upon themselves to create an offence that Parliament had specifically refused to create? And even if that did happen, how could he reasonably have foreseen that the time honoured rule against retrospectivity would be ignored or rationalised out of existence?

$R \quad v$ Crooks shows how legally dangerous the application of this reasonable forseeability rule has become. First, Crooks had involuntary intercourse with his wife in 1970. If he had delayed that act for 6 years, until Parliament decided that marriage should still be a defence, in 1976, what then could he reasonably have been expected to foresee? Secondly, the Court disagreed with the submission that the defendant, seeking legal advice in 1970, would have been told that he would not be committing a criminal offence. The Court said that a solicitor would have told his client "that the courts had developed, and could be expected to continue to develop, exceptions to the supposed rule of irrevocable consent, and that, if ever the issue were considered by the Court of Appeal, the supposed immunity of the husband from a successful prosecution for the rape of his wife might be recognised for what it was, a legal fiction.” But the issue was retrospectivity: does any of this explain why an advising solicitor might suppose that the developed law would apply retrospectively? Thirdly, the Court's view was that Article 7 (2), allows retrospection where the behaviour has been criminal according to the general principles of law recognised by civilised nations. Is it seriously being suggested that because Parliament had decided against marital rape, that we were not a civilised nation? Fourthly, the Court said that "examining the entire purpose of the Convention, the wife was entitled to protection from inhuman or degrading treatment and indeed from the destruction of any of the rights and freedoms protected by the Convention.” But if the broader principles of the Convention suffice to cover such issues, one wonders why the draughtsmen found it necessary to include Article 7 at all? It is submitted that these arguments defy common-sense.

\section{CONCLUSIONS}

There is, of course, no moral reason whatsoever for protecting rapists, and the law has been rightly getting tougher in its dealings with them. It may well be that no great moral injustice was done in Laskey's case, although where a wife, after the "rapes", continues to co-habit for several years, a ten year sentence might be thought to be somewhat harsh. 


\section{THE DENNING LAW JOURNAL}

But what of the legal injustice? Is a country which is rightly proud of the supremacy of the rule of law, to be seen to be straining to uphold convictions for marital rape by reliance upon manifestly flawed legal arguments and a contrived interpretation of the concept of forseeability, in order to circumvent fundamental principles of law which have protected our citizens throughout the centuries?

One does not have to be a supporter of 'rapacious husbands' or make light of the appalling evidence in these cases, to see that the precedent of the highest courts thumbing their noses at the rules of law they are meant to safeguard, and seeming to uphold the dangerous concept that ends justify the means, does not bode well for justice. Nor does the spectre of the European Court of Human Rights fudging the rules it is meant to safeguard, look good for the preservation of those rights.

It may be that the European Court will not be too anxious to get into a debate about whether the highest Court in a sovereign State, acted "ultra vires" its powers in making new law: questions of sovereignty apart, a back$\log$ of 68,000 cases, when only 3000 are currently being processed a year, is likely to dull any enthusiasm. But it might certainly help to relieve the forces of constitutional conflict, now raging between government and the judiciary, if the Judicial Committee of the House of Lords were to take an early opportunity to restate definitively the limits of its powers. And it would surely increase the respect in which the European Court is held, if it were seen to be strong and unequivocal in upholding its own Convention, which guarantees the protection of human rights, by declaring that the rules that there should be no punishment without law and no retrospective application of laws, mean exactly what they say.

For if neither of our guardians, the House of Lords or the European Court of Human Rights, do the right thing by the law, might we not ask who in the end is there to protect the individual in our society? 